\title{
THE CHALLENGES FOR COURT REFORM AFTER AUTHORITARIAN RULE: THE ROLE OF SPECIALIZED COURTS IN INDONESIA
}

\author{
Melissa Crouch ${ }^{*}$ \\ The University of New South Wales (Sydney), UNSW, Australia \\ melissa.crouch@unsw.edu.au
}

Received: 1 June 2020 | Last Revised : 1 March 2021 | Accepted: 22 April 2021

\begin{abstract}
Political transitions from authoritarian rule may lead to a process of court reform. Indeed, court reform has been a central pillar of the law and development movement since the 1960s. What challenges do court reform efforts face after authoritarian rule in Indonesia and to what extent can specialized courts address these challenges? In this article, I examine court reform and the establishment of specialized courts in Indonesia post-1998. I argue that we need to pay attention to the politics of court reform after authoritarian rule. Specialized courts as a type of institutional reform need to be considered together with judicial culture in order to address fundamental challenges in the courts.
\end{abstract}

Keywords: Authoritarian Rule, Corruption, Court Reform, Judicial Independence.

\section{INTRODUCTION}

Political transitions from authoritarian rule may lead to a period of judicial reform. Indeed, court reform has been a central pillar of the law and development movement since the 1960s. An agenda for court reform after authoritarian rule is often motivated by the desire to address entrenched corruption in judicial practice and enhance the independence of the courts in relation to the other branches of government.

\footnotetext{
Professor and Associate Dean Research at Faculty of Law, University of New South Wales.
} 
One common institutional reform has been the creation of specialized courts. Specialized courts are a response to several key issues common to democratizing regimes. One issue is the lack of judicial expertise and professionalism. Another issue is the need to ensure fairness and justice, which is challenged by corruption in the courts. Further issues are the lack of legal certainty, as well as inefficiency and inconsistency, in the functioning of the courts. Specialized courts respond to these concerns by seeking to enhance judicial expertise and professionalism; eliminate or reduce incentives for corruption by insulating the specialized court from the general courts; and by introducing distinct procedures to enhance efficiency, certainty and consistency. The trend towards judicial specialization can

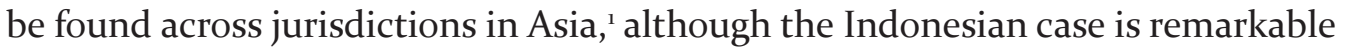
in the scale and breadth of areas of specialization.

In this article, I consider the challenges court reform efforts face after authoritarian rule in Indonesia and the extent to which specialized courts can address these challenges. I identify the key challenges that specialized courts are said to address, including the issue of corruption, a lack of professionalism and expertise, and legal uncertainty. I affirm socio-legal scholarship on the concept of legal culture as a way of understanding courts as institutions that work within networks of power. The work of Daniel S. Lev, a political scientist and Indonesianist, promotes the empirical study of the concept of legal culture as one means to understand the politics of courts.

I consider the extent to which specialized courts address the concerns Lev identified in Indonesia's legal system and whether judicial culture in the specialized courts is distinct from the general courts. Indonesia's contemporary judicial landscape features at least thirteen different types of courts. These include the creation of a specialized Constitutional Court, a Tax Court, a Human Rights Court, a Fisheries Court, an Anti-corruption Court and a Commercial Court, among others. I identify the common techniques adopted by specialized courts, such as appointing a majority of non-career judges to ensure judicial independence; providing specialized judicial training to enhance expertise;

Pip Nicholson and Andrew Harding, New Courts in Asia (London: Routledge, 2010). 
and introducing streamlined procedures to increase access to justice. I suggest that these courts offer the promise of enhancing professionalism and expertise, and reducing corruption, because the judges on these courts are more often ad hoc judges rather than career judges. Yet the initial set-up phase of a court is crucial to ensuring it meets these goals, and as creatures of legislation, subsequent amendment by parliament may threaten the powers, and ultimately the independence, of these courts.

\section{COURTS AND LEGAL CULTURE}

Law reform often focuses on the technical or institutional aspects of reform, yet consideration of legal culture is also important. Legal culture as a concept has received significant scholarly attention over recent decades. The study of legal culture spans several fields, including anthropology, comparative law, and law and society. ${ }^{2}$ I suggest that central to the study of legal culture is the concern over power, authority and equality. ${ }^{3}$ This is why legal culture matters for court reform during times of political transition.

The literature on legal culture focuses on debates over the meaning of the term and whether the term 'legal culture' remains useful and coherent. The work of Susan Silbey has been influential in this area. ${ }^{4}$ Silbey attributes scholarly interest in legal culture to the shift from the study of law and society to the study of law in society, or the cultural turn. Increasingly in the 1980 s and 1990 , the focus on legal culture began to overlap with ideas of legal consciousness, understood as the study of public perceptions about law, and the use of law and the courts. Silbey is one example of a scholar who championed the concept of

Sally Engle Merry, "What is Legal Culture? An Anthropological Perspective," Journal of Comparative Law 5 (2010): 40. Lawrence Rosen, Law and Culture: An Invitation (Princeton: Princeton University Press, 2006).

4 Another example in the debate over legal culture is the long-standing interchange between Roger Cotterrell and David Nelken: Roger Cotterell, Law, Culture and Society: Legal Ideas in the Mirror of Social Theory (Aldershot: Ashgate, 2006); Roger Cotterell, "The Sociological Concept of Law," Journal of Law and Society 10 (1983): 241-55; David Nelken, "Towards a Sociology of Legal Adaptation," in Adapting Legal Cultures, eds. David Nelken and Johannes Feest (Oxford: Hart Publishing, 2001); David Nelken, "Legal Cultures," in The Blackwell Companion to Law and Society, ed. Austin Sarat (Malden: Blackwell Publishing, 2003), 113-27; David Nelken, "Comparative Legal Research and Legal Culture: Facts, Approaches, and Values," Annual Review of Law and Social Science 12 (2016): 45-62.

5 See also Annelise Riles, "A New Agenda for the Cultural Study of Law: Taking on the Technicalities," Buffalo Law Review 53 (2005): 973-1033. 
legal culture, ${ }^{6}$ like Lev, only later to retreat on the use of the term.7 Sally Engel Merry $^{8}$ and David Engel ${ }^{9}$ emphasize the need to shift attention away from circular debates about the meaning of the term legal culture, and instead reaffirm its usefulness as a key concept in socio-legal research.

Merry identifies four distinct uses of the term 'legal culture'10 and this is endorsed by other scholars such as Engel." The first two ways of understanding legal culture, Merry suggests, are: (1) as the practises and ideologies within the legal system, and (2), as the public attitudes towards the law. She sees these two concepts as analogous to Lawrence Friedman's complementary ideas of internal and external legal culture. Merry's two additional approaches to legal culture are legal mobilisation and legal consciousness. Legal mobilisation refers to why and how people articulate their problems in legal terms. Legal consciousness concerns how individuals experience the law and understand its relevance to their lives. Examples of this in the context of Indonesia are Hikmahanto Juwana's study of public perceptions of the courts ${ }^{12}$ and the Asia Foundation's citizen assessment of perceptions of justice in Indonesia. ${ }^{13}$

Simon Halliday and Bronwyn Morgan ${ }^{14}$ also affirm the value in inquiries of legal culture. Like Merry, they argue that legal culture and its relation to legal consciousness remains an important field of inquiry. In this article, I am particularly concerned with the legal culture of the courts and the judiciary specifically. That is, I am referring to legal culture as the internal culture of the courts, and the practices and ideologies of the judiciary. The concept of legal culture is relevant to understanding the politics of court reform. From this basis, I turn to consider the politics of court reform in Indonesia since 1998.

\footnotetext{
Susan S. Silbey, "Making a Place for Cultural Analyses of Law," Law \& Social Inquiry, Vol. 17, no. 1 (Winter, 1992): 39-48.

Susan S. Silbey, "After Legal Consciousness," Annual Review of Law and Social Science 1 (2005): 323-68.

Merry, "What is Legal Culture?"

9 David M. Engel, "The Uses of Legal Culture in Contemporary Socio-Legal Studies: A Response to Sally Engle Merry," Journal of Comparative Law 5 (2010): 59-65.

10 Merry, "What is Legal Culture?"

11 Engel, "The Uses of Legal Culture."

12 Hikmahanto Juwana, "Courts in Indonesia: A Mix of Western and Local Character," in Asian Courts in Context, eds. Jiunn-rong Yeh and Wen-Chen Chang (Cambridge: Cambridge University Press, 2014), 303-339.

13 The Asia Foundation's preliminary citizen assessment of perceptions of justice (2001) in Indonesia.

14 Simon Halliday and Bronwyn Morgan, "I Fought the Law and the Law Won? Legal Consciousness and the Critical Imagination," Current Legal Problems 66 (2013): 1-32.
} 


\section{THE POLITICS OF COURTS: THE CONTRIBUTION OF DAN}

\section{S. LEV}

One way to approach the study of legal culture and the politics of court reform is to consider how the courts have changed over time. Dan S. Lev was an Indonesianist whose work offers deep analysis of the role and status of the courts under the Suharto regime. I suggest that Lev's grounded, empirical commitment to his research informed his approach to the study of legal culture and the politics of courts.

Lev was writing in the post-colonial era when Indonesia and other postcolonial states from Asia to Africa were struggling with the task of nationbuilding. In this light, Lev consistently called for 'problem focused research'. ${ }^{15}$ He argued for the need for 'deep research' in a similar vein to Geertz's 'thick description'. ${ }^{16}$ Lev had little tolerance for work that took legal text at face value or divorced from political context. ${ }^{17}$ He saw no use for analysis of legal text if that analysis was void of context. His work encouraged empirical inquiry. ${ }^{18} \mathrm{He}$ modelled this approach in his own work, which was based on extended field research, interviews, media analysis, analysis of legal texts, court observation and local academic commentary. ${ }^{19}$

Lev's pioneering work on the Islamic courts in Indonesia was not only unusual in the field of Islamic studies (with its heavy and almost exclusive focus on the Middle East), but the Islamic Courts were a topic that had never been thoroughly considered in the context of Indonesia..$^{20}$ Likewise, there had been little attention to the courts, the prosecution, the police, and the legal profession, and the relationship between the two prior to Lev's seminal work.

15 Daniel S. Lev, "Islamic Courts in Indonesia: A Study in the Political Bases of Lega; Institutions," Bulletin of the School of Oriental and African Studies 38, no. 1 (December 2009): 224.

16 Clifford Geertz, "Thick Description: Toward an Interpretive Theory of Culture," in The Interpretation of Cultures: Selected Essays (New York: Basic Books, 1973).

17 Lev, "Islamic Courts in Indonesia," 1.

18 Daniel S. Lev, Legal Evolution and Political Authority in Indonesia: Selected Essays (The Hague: Kluwer Law International, 2000), 11.

19 Daniel S. Lev, "The Politics of Judicial Development in Indonesia," Comparative Studies in Society and History 7 (1965): 173-202; Lev, Islamic Courts in Indonesia, xi.

20 Lev, "Islamic Courts in Indonesia," see also Melissa Crouch, "Islamic Law and Society in Southeast Asia," in The Oxford Handbook on Islamic Law, eds. Anver M. Emon and Rumee Ahmed (Oxford: Oxford University Press, 2016). 
He was particularly concerned with methods that could capture legal change and continuity in new states-post-colonial Indonesia being his primary focus. Lev argued that:

In order to understand legal systems in the midst of political transformation, we must examine them from the ground up to find out what sort of political and social space is allotted to them, what kinds of functions they are permitted to serve, encouraged to serve, and forbidden to serve. ${ }^{21}$

Lev was concerned with the Indonesian experience of legal change and how the space for legal institutions changed over time..$^{22}$ He sought to illuminate the evolution of local law and legal institutions, not in misleading isolation but in full consciousness of its political, economic and social settings. He was also acutely aware, and called out, the bias towards European and North American legal experience as the criteria for evaluation of other legal systems. This relates to his concern with the production of power and the 'struggle over the political and ethical dimensions of the Indonesian state. ${ }^{23}$ Lev devoted his career to understanding the intimate relationship between political and legal authority and structure. ${ }^{24}$ Lev advocated cross-institutional research, that is, to undertake research that understands the courts as one institution in relationship to other institutions, both state and non-state institutions. Lev supported the study of courts as part of the wider social environment and in light of connections between the judiciary and other institutions.

Lev maintained a commitment to sustained empirical research as a means of generating theory. Lev's work is primarily empirical rather than theoretical. Lev draws on Lawrence Friedman's ${ }^{25}$ concept of legal culture (as mentioned earlier) as 'the network of values and attitudes related to law, which determines when and why people turn to law or government, and when they turn away'. ${ }^{26}$

\footnotetext{
21 Lev, "Islamic Courts in Indonesia," 2.

22 Daniel S. Lev, "Comments on the Course of Legal Reform in Modern Indonesia," in Indonesia: Bankruptcy, Law Reform, and the Commercial Court, ed. Tim Lindsey (Sydney: Desert Pea Press, 2000).

23 Daniel S. Lev, "Between State and Society: Professional Lawyers and Reform in Indonesia," in Making Indonesia, eds. Daniel S. Lev and Ruth McVey (Ithaca: Cornell Southeast Asia Program Publications, 1996), 319.

24 Lev, "Comments on Judicial Reform Program."

25 Lawrence Friedman, "Legal Culture and Social Development," Law and Society Review 4 (1969): 29-44.

26 See also Lawrence Friedman, Law and Society: An Introduction (Englewood Cliffs: Prentice-Hall, 1977).
} 
However, through Lev's methodology, he demonstrated the value of empirical studies for analysing the politics of courts and legal culture.

Following Friedman, Lev argues that there are two main concepts: legal system and legal culture. ${ }^{27}$ He defines a 'legal system' as the formal processes and procedures, which include formal institutions, such as bureaucracies and the courts, and how they manage conflict and resources of authority, roles they rely upon. The legal system is legitimated and receives its authority from the political system and it is used as a tool for social management. He argues that 'legal systems are politically derivative and cannot be understood apart from political structures, interests, ideology and the conflicts they incur..$^{28}$ Lev starts with an understanding of a legal system as the 'skeleton of the modern state'29 and the attendant calls for the rule of law as a pillar of modernization.

Lev goes on to define 'legal culture' as the values that underlie the law and legal process. This includes procedural legal values and substantive legal values, which are often polar opposites and can change over time. Lev argues that law is 'fundamentally dependent upon political reception of legal process - its habits, ideology, principles and controls-and the willing submission, within limits usually, of political leadership to legal constraint ${ }^{30^{\prime}}$. This notion of law is heavily reliant on politics and political process. Lev considers legal culture in the context of studying patterns of change in Indonesia's legal since the 1945-59 independence revolution and in particular explores how judicial institutions relate to political processes and cultural values. ${ }^{31}$ Institutionally, Lev sees the courts as a 'subsystem of a larger administrative apparatus' ${ }^{32}$ and as institutional creatures with specific interests and ambitions. 33

\footnotetext{
27 Daniel S. Lev, "Judicial Institutions and Legal Culture," in Culture and Politics in Indonesia, ed. Claire Holt (Ithaca, NY: Cornell University Press, 1972), 247.

28 Daniel S. Lev, "Introduction," in Legal Evolution and Political Authority in Indonesia: Selected Essays (The Hague: Kluwer Law International, 2000), 3.

29 Lev, "Introduction," 1.

30 Daniel S. Lev, "Conceptual Filters and Obfuscation in the Study of Indonesian Politics," Asian Studies Review 29, no. 4 (2005): 345-56, 354.

31 Lev, "Judicial Institutions and Legal Culture."

32 Lev, "Islamic Courts in Indonesia," 122.

33 Lev, "Politics of Judicial Development," 173.
} 
The symbolic function of law and its relationship to authority was also of concern to Lev. He was attentive to a range of sources of authority, from state authority to religious authority. He notes 'legal systems and law are symbols, and what they are symbolic of, inter alia, is authority, not necessarily coercive authority, but social and political authority, which by its legitimacy, its social rightness, earns loyalty and a measure of compliance.'34

Lev also tended towards an expansive definition of law: 'law is many things, serves many functions in society, and can be usefully defined in many different ways'. He was clear that his focus was not just on formal legal structures and legal rules, although he included these in his analysis. Rather, he was concerned with both law and legal institutions in terms of how structures and rules are understood, variously used, manipulated, accepted, avoided and so on, along with all the informal structures and modes of action that this kind of definition implies'.35

In many respects, Lev's body of work was committed to exploring and explaining legal culture in Indonesia. His criticism of the broad term 'culture' came later in his career and after he had spent several decades working on legal culture in Indonesia. Lev cautioned against the dangers and misuses of culture as a grand myth. ${ }^{36}$ He focuses on interest, ideology, organization and power as the primary factors that shape political orders and the legal systems they support'.37 Further, Lev calls for restraint and sensitivity to the 'weaknesses, shortcomings and dangers of cultural analysis' and avoidance of 'oversimplification inherent' in cultural analysis. ${ }^{38}$ Overall, Lev's work on Indonesia's courts suggests a conception of legal culture that is conscious of and attentive to power relations, while avoiding the pitfalls of a simplified cultural analysis.

\footnotetext{
Lev, "Islamic Courts in Indonesia," 263.

Lev, "Islamic Courts in Indonesia."

Lev, Legal Evolution, 5.

Lev, "Conceptual Filters."

Lev, "Conceptual Filters," 346.
} 


\section{COURT REFORM THROUGH SPECIALIZED COURTS}

The dramatic end of Suharto's authoritarian regime in 1998 ushered in two decades of law reform, which included by constitutional reforms, legislative reforms and major institutional reforms. The constitutional and political system has undergone major changes and legal reform. The courts have been restructured and imbued with new powers as part of these efforts at law reform. The judiciary has changed due to constitutional amendments designed to enhance the independence of the courts from the executive and reinforce the concept of the separation of powers in the Constitution. ${ }^{39}$ At the same time, judges have come under renewed scrutiny with the constitutional establishment of the Judicial Commission, and the creation by law of the Corruption Eradication Commission.

The contemporary Indonesian judicial landscape includes both the general courts and specialized courts, as well as various independent accountability agencies. The post-colonial Indonesian judicial system has been influenced by a wide range of sources, both domestic and global, from international human rights norms to local understandings of Islamic law and adat (customary) law, as well as the persistence of the Dutch legal legacy. Two concepts are important to both the past and present legal system in Indonesia: the rule of law, negara hukum, and the separation of powers, trias politika. ${ }^{40}$

Taken as a whole, there are common patterns and trends in legal culture across what appear to be vastly distinct judicial institutions. I consider why a special courts strategy was adopted, that is, the problems it sought to resolve and to with what impact. What were the challenges of court reform after Suharto's authoritarian rule? And to what extent have specialized courts overcome these challenges?

To understand the problems with legal culture, specialized courts need to be considered in light of the general court system, rather than in isolation from it. Since independence in 1945, the core of the judicial system has been the

\footnotetext{
39 Denny Indrayana, Indonesian Constitutional Reform 1999-2002: An Evaluation of Constitution-Making in Transition (Jakarta: Kompas, 2008).

40 Lev, "Politics of Judicial Development," 184.
} 
Supreme Court at the apex of the general court system. ${ }^{41}$ Below the Supreme Court is a complex network of lower courts spread across Indonesia's 34 provinces, hundreds of cities and regencies, and thousands of districts. Under Suharto's New Order, the Supreme Court and the subordinate courts were notorious for corruption. Lev was openly critical of the decline in the standards and status of the judiciary. Under Suharto, the increase in corruption within the bureaucracy, and particularly within the judiciary, is well known. In his observations on the decline in professionalism and rapid rise of corruption, Lev went as far as to label judges the 'judicial mafia'.42 This legacy continues today and, as Rifqi Assegaf has identified, a consequence of corruption in the courts is the lack of legal certainty. ${ }^{43}$ Despite the establishment of a Judicial Commission, its powers have been reduced and it has a strained relationship with the Supreme Court, which often fails to act upon recommendations of the Judicial Commission to discipline judges.

The reform era is characterized first by changes to the general court system through constitutional and legislative means, and then by the introduction of a growing number of specialized courts. The independence of the general court system was affirmed through constitutional reform, and the separation of powers mandated in an explicit effort to reduce executive influence over the courts. In particular, the long-held demands for judicial independence resulted in the 'one-roof reforms', in which control over court administration shifted from the executive to the judiciary. In the past, justice was administered under 'two roofs', the executive as represented by the Ministry of Justice, and the Ministry of Religion, and the judiciary as represented by the Supreme Court and Religious Courts. This meant that matters of budget allocation, appointments, discipline and court administration were subject to the influence and interference of the

${ }_{41}$ Sebastiaan Pompe, The Supreme Court of Indonesia: A Study of Institutional Collapse (Ithaca: Cornell University Press, 2005).

42 Daniel S. Lev, "Between State and Society: Professional Lawyers and Reform in Indonesia," in Making Indonesia eds. Daniel S. Lev and Ruth McVey (Ithaca: Cornell Southeast Asia Program Publications, 1996), 310.

43 Rifqi Assegaf, "The Supreme Court: Reformasi, Independence and the Failure to Ensure Legal Certainty," in The Politics of Court Reform: Judicial Change and Legal Culture in Indonesia, ed. Melissa Crouch, (Cambridge, Cambridge University Press 2019), 31-58. 
executive. From the 1960s to the 1990s, this had been one of the main causes of concern and grievance for rule of law advocates.

The post-1998 constitutional and legislative reforms changed all this and gave jurisdiction over all matters of court administration and the lower courts to the Supreme Court. The 'one-roof reform' promised a culture of judicial independence, judicial control over the budget and court administration, the absence of executive interference, and greater efficiency in the execution of justice. There was an attempt to balance this expansion of judicial power with the creation of the Judicial Commission as an accountability mechanism enshrined in the Constitution, whose mandate is explained further in legislation. Within the Supreme Court, the year 2001 marked the start of major reforms led by Chief Justice Bagir Manan. ${ }^{44}$ The Supreme Court continues its long-term reform agenda today under the Supreme Court Blueprint 2010-2035.

The first contemporary additions to the general court system in the 198 os were the Administrative Courts based on a Dutch civil-law model, and the Religious (Islamic) Courts (which existed in a different form prior to being unified across the country). The creation of the Administrative Courts in 1986 marked the beginning of a contemporary trend to establish specialized courts. ${ }^{45}$ Since that time, the establishment of new courts includes the Juvenile Courts in 1997; the Commercial Courts in 1999; the Syariah Courts for the province of Aceh in 2002; the Human Rights Court in 2000; the Tax Court in 2002; the Constitutional Court in 2003; the Industrial Courts in 2004; the Anti-Corruption Court in 2004 and then in 2010 the provincial Anti-Corruption Courts; the Fisheries Court in 2009 (although it did not commence until 2014); and the Small Claims Court in 2013. Many of these courts have undergone major revisions to their powers and processes since establishment, such as the 2012 reforms to the Juvenile Courts.

I suggest that these specialized courts take one of two institutional forms. Some specialized courts are a separate and independent entity. These specialized courts have their own personnel, court buildings and procedures, such as the

44 Rifqi Assegaf, "The Supreme Court: Reformasi."

45 Adriaan Bedner and Herlambang Perdana Wiratraman, "The Administrative Courts: The Quest for Consistency," in The Politics of Court Reform: Judicial Change and Legal Culture in Indonesia, ed. Melissa Crouch, (Cambridge, Cambridge University Press 2019), 133-148. 
Constitutional Court, the Administrative Courts and the Religious Courts. I call these 'independent specialized courts'. They can be said to operate independent from the general court system, although there is still an avenue of appeal from these courts to the Supreme Court, as is the case with the Administrative Courts, Military Courts and Religious Courts. Although these courts have a constitutional mandate, they still face challenges. The Constitutional Court faced significant logistical challenges in its first year of operation in terms of its premise and budget, similar to the challenges other newly-established specialized courts have faced. Similarly, both the Industrial Relations Court and the Human Rights Court failed to pay their ad hoc (non-career) judges in the first few months or years of the courts' existence. ${ }^{46}$ This forced judges to find other sources of income out of necessity. The set-up phase of a new court, and the need to ensure support from either (or both) the Supreme Court and the executive is often crucial in establishing a specialized court that has legitimacy and long-term viability.

The second type of court are specialized courts that exist within the scope of another court (usually the district or provincial courts). These specialized courts use the same buildings, are often subject to the same procedure and involve career judges from the general courts. I call these 'dependent specialized courts' in the sense that institutionally the courts are still reliant on the infrastructure, knowledge and personnel of the general court system. They do not have a separate and independent existence from the general court structure, but rather remain dependent on it. These dependent specialized courts include the Industrial Relations Courts, the Juvenile Courts, the Commercial Courts, the Anti-Corruption Courts, the Fisheries Courts, the Small Claims Courts, the Human Rights Courts, and the Tax Courts. All of these are under the general courts with the exception of the Tax Courts, which are within the Administrative Courts.. All of these are under the general courts with the exception of the Tax Court, which is within the Administrative Courts. By thinking of these courts as dependent specialized courts, it puts their function and the scope

${ }^{46}$ Ken Setiawan, "The Human Rights Courts: Embedding Impunity," in The Politics of Court Reform: Judicial Change and Legal Culture in Indonesia, ed. Melissa Crouch (Cambridge, Cambridge University Press 2019), 287-310; Surya Tjandra, Labour Law and Development in Indonesia (Leiden: Leiden University Press, 2016). 
of their mandate in perspective with the rest of the court system. Although its jurisdiction, mandate and powers may be distinct from the general court, the function of the court remains closely connected to the general courts. This means that they are less insulated from the problems of the general courts. In this model, support of the Supreme Court, which oversees the general courts, is crucial. Some specialized courts also have strong connections to the executive or independent agencies - for example, the Fisheries Court is closely related to the Ministry of Maritime Affairs and Fisheries, and the Anti-Corruption Court is closely related to the Anti-Corruption Commission.

Specialized courts share other common characteristics. Most specialized courts are permanent, although some have gradually expanded their location over time. Only one, the Human Rights Courts, has both permanent and ad hoc courts. After 2000, a permanent human rights court was established in Makassar, and there are provisions for its establishment in Central Jakarta, Surabaya and Medan. Ad hoc human rights courts can also be established for crimes committed prior to 2000.47

Most specialized courts are not specifically named in the Constitution. The legislature has the power to define the jurisdiction and powers of specialized courts. Four courts have explicit constitutional recognition: the Constitutional Court, Administrative Courts, Military Courts and Religious Courts. Specialized courts created by legislation are dependent on the goodwill of the government for their existence and the scope of their powers. Some courts have had their powers expanded and enhanced, such as the 2012 reforms to the Juvenile Courts. But other courts have had their powers reduced, such as changes to the powers of the Constitutional Court through the 2011 and 2014 amendments to the law. Further, if courts are only established by legislation and do not have a constitutional basis, they face the risk of disestablishment. This is the case with the Fisheries Court, which has been threatened with closure. ${ }^{48}$

\footnotetext{
47 Mark Cammack, "Indonesia's Human Rights Court," in New Courts in Asia, eds. Andrew Harding and Pip Nicholson (London: Routledge, 2010).

48 Indriaswati Dyah Saptaningrum, "The Fisheries Court: Government-Led Judicial Development," in The Politics of Court Reform: Judicial Change and Legal Culture in Indonesia, ed. Melissa Crouch (Cambridge, Cambridge University Press 2019), 218-244.
} 
Some specialized courts have a long legal history or have existed in different forms prior to their creation. This includes the Religious Courts; ${ }^{49}$ the Tax Court that was preceded by a tribunal since 1915; and the Industrial Relations Court that was preceded by an administrative body since the 196os. The establishment of the Syariah Courts (Mahkamah Syari'ah) in Aceh was unusual and was the result of Aceh's status as a province with special autonomy. The jurisdiction of these courts is similar to, but more expansive than, the Religious Courts in other provinces and has been covered extensively elsewhere..$^{\circ}$

The location of specialized courts affects the ability of people to access the court. With 34 provinces, 514 cities or regencies, and thousands of districts, the location of a court matters for access to justice. Some courts are centralized and only exist in the capital city, Jakarta, such as the Constitutional Court and Supreme Court. The general court system exists in every township and district. Specialized courts vary in the scope of their geographic coverage. Some, like the Human Rights Court, are only intended to exist in four set locations. Other courts, like the Anti-Corruption Courts, now exist in every district court across Indonesia. ${ }^{51}$ Regionalization is therefore an important criterion for court reform, as it aims to enhance access to justice, as the lack of local coverage has meant that courts such as the Industrial Relations Court, which only exist at the provincial level and not at the district or township level, are difficult to access..$^{52}$

Specialized courts in Indonesia have three key characteristics: a specialized jurisdiction; a unique judicial selection and composition process, often having a majority of non-career or expert judges on the bench; and specialized investigation and determination procedures, differing from the general courts and designed to be more efficient.

49 Lev, "Islamic Courts in Indonesia."; Stijn Cornelis van Huis. "The Religious Courts: Does Lev's Analysis Still Hold?" in The Politics of Court Reform: Judicial Change and Legal Culture in Indonesia, ed. Melissa Crouch (Cambridge, Cambridge University Press 2019), 109-132.

5o See Michael Feener, Sharia and Social Engineering: The Implementation of Islamic Law in Contemporary Aceh, Indonesia (Oxford: Oxford University Press, 2014).

${ }^{51}$ Simon Butt, "Indonesia's Anti-corruption Courts and the Persistence of Judicial Culture," in The Politics of Court Reform: Judicial Change and Legal Culture in Indonesia, ed. Melissa Crouch (Cambridge, Cambridge University Press 2019), 151-173.

52 Tjandra, Labour Law and Development. 
An important reform measure that spans both general and specialized courts is the increase in non-career, ad hoc or expert judges.53 In Indonesia's civil law system, judges in the general court system are typically career judges selected through a process of closed recruitment. ${ }^{54}$ While there was a history of occasional external appointments to judicial office, ${ }^{55}$ this practice diminished under the New Order. The appointment of non-career judges then occurred with the creation of the Administrative Courts, although this recruitment option was later abolished. ${ }^{56}$ In 2000, non-career judges were appointed to the Supreme Court and Bagir Manan became the first non-career judge to hold the office of Chief Justice. Most specialized courts have a majority of non-career judges, though the ratio of non-career to career-judges varies.

Broadly speaking, the non-career judges constitute the majority on any bench hearing a case in a specialized court. The composition of the bench is intentional because non-career judges are perceived to be clean or at least less likely to be caught up in the trap of corrupt practices commonly perceived as inherent in the general judiciary. This has, however, not always been the case, such as the 2012 case of a non-career judge in Semarang jailed for corruption. ${ }^{57}$ Further tensions complicate the role and independence of non-career judges. For example, in the Industrial Relations Court, some judges are selected by trade unions while other judges are selected by corporate lobby groups. Surya Chandra has pointed out that knowledge of which side a judge was appointed by creates a dilemma for these judges when it comes to deciding for or against parties in cases..$^{8}$

There are common issues and shared problems that have arisen in the establishment of specialized courts. Many issues arise from the broader lack of professionalism, incompetence and corruption that have long been identified

\footnotetext{
The terms 'non-career', 'ad hoc' or 'expert' judge are used interchangeably in this article.

54 On judges as career judges, see Martin Shapiro, Courts, a Comparative and Political Analysis (Chicago: University of Chicago Press, 1981), 150; Pompe, The Supreme Court of Indonesia.

55 Pompe, The Supreme Court of Indonesia, 25.

${ }^{6}$ Adriaan Bedner, Administrative Courts in Indonesia: A Socio-Legal Study (The Hague: Kluwer Law International, 2001).

57 Butt, "Indonesia's Anti-corruption Courts and the Persistence of Judicial Culture,", 166.

${ }^{8}$ Surya Tjandra, "Labour Law and Development in Indonesia" (PhD thesis, Leiden University, 2016).
} 
with the general court system, first by Lev and then by many others since. ${ }^{59}$ Many of the problems of establishing specialized courts arise in relation to the role and position of ad hoc judges. Given that career judges already receive a wage, payment and recognition of their role sitting on the bench of a specialized court is often not an issue. Instead, it is often the new ad-hoc judges who are delayed in receiving their wage. A failure to get paid or delays in payment may require judges to find funds from alternate means.

Another problem is that the wage of career judges as civil servants is exempt from taxation. This is a significant monetary benefit for career judges. In contrast, non-career judges, who are not classified as civil servants, must pay 15 percent tax..$^{60}$ This is a disincentive to take on the role of a non-career judge, and creates inequality between career and non-career judges.

While space for non-career judges on specialized courts is an opportunity to bring in experts from academia, business and civil society into the judiciary, this is not without difficulties. The need to offer specialized training to noncareer judges is important. From the perspective of career judges, non-career judges are often perceived to lack judicial experience and are considered to be unfamiliar with court procedure and decision-making. Further, non-career judges are not subject to a rotation system, unlike career judges, and so are able to stay within one specialized court and build up knowledge over a period of time. The one issue that runs against this is that the terms of non-career judges are often only five years, so once their term is up, new candidates with the relevant qualifications are needed to staff the court.

There are common motivations for the establishment of specialized courts. Both international actors and external donors see the creation of a specialized court as a means of insulating a judicial body from the general courts, creating a body of legal precedent and enhancing certainty and consistency in decisionmaking. But the legal sector in Indonesia does not place high value on following court decisions, either in law school (where cases are not read) or in legal or

59 See, e.g., Pompe, The Supreme Court of Indonesia.

6o Tjandra, Labour Law and Development, 217. 
judicial practice. The desire to circumvent the corruption endemic to the general court system and to career judges in general is a prominent reason for the creation of specialized courts.

A further reason is the recognition of new and emerging areas of law that require high levels of specialization. The creation of courts with non-career judges is a means of bringing people with expertise, such as academics or industry experts, onto the bench.

Some specialized courts, such as the Commercial Courts, are the direct result of conditionality loans imposed by external donors such as the IMF. ${ }^{61}$ Lev notes that 'uninformed foreign pressure meant to bring about dramatic and quick improvement in legal process has little or no hope of success.' ${ }^{62} \mathrm{He}$ clearly had little patience for developments such as the Commercial Courts, part of a conditionality of an agreement with the IMF. ${ }^{63}$ Other courts, like the Human Rights Court, are the result of international pressure on the Indonesian government to deal with human rights violations. In many respects, the court was established to avoid the prospect of facing an international court. This suggests the motives for establishing specialized courts are not necessarily in line with accountability and justice. The motivation for creating other specialized courts is driven by protecting domestic interests, such as the establishment of the Fisheries Court as a means of protecting Indonesia's waters from illegal fishing activities by foreign individuals or corporations.

The challenges of court reform after authoritarian rule are enormous. Specialized courts cannot address these challenges in isolation. What specialized courts have been able to do is offer creative efforts to address particular issues and facilitate the overall expansion of the court system. Lev cautions us to be realistic when it comes to judicial reform. He argues that legal reform is only likely when new political elites take legal process seriously. He also suggests that

\footnotetext{
61 Gustaaf Reerink, Kevin Omar Sidharta, Aria Suyudi and Sophie Hewitt, "The Commercial Courts: A Story of Unfinished Reforms," in The Politics of Court Reform: Judicial Change and Legal Culture in Indonesia, ed. Melissa Crouch (Cambridge, Cambridge University Press 2019), 174-197.

62 Lev, "Conceptual Filters," 354.

63 See Reerink et al., "The Commercial Courts," 174-197.
} 
the conditions and structures of political power need to be examined to ensure a firm basis for any program of legal reform. Lev argues that fundamental, deep reform can be addressed in two ways: radical and quick (but often shallow) reform, or relatively slow, gradual reform, which is more expensive and requires more sophisticated strategies over the long run. Lev does warn that fundamental reform, deep reform, takes a long time. He argues that it is only when the political elite agrees to take certain ideas or processes seriously that these reforms will be meaningful. The elite within Indonesia's legislature and executive, and to some extent the Supreme Court, have been remarkably willing to experiment with the idea of specialized courts as a mode of reform. Specialized courts have fundamentally changed the judicial landscape by popularizing the role of ad hoc judges and attempting to ensure greater expertise and independence in the judicial process.

\section{CONCLUSION}

Court reform after authoritarian rule involves both institutional reform and a shift in legal culture. Any attempts at judicial reform must inevitably acknowledge the pre-existing legal culture and the problems inherent in the judicial process under authoritarian rule - which may range from the capture of the courts by the executive, to corruption, to a decline in professional standards and expertise.

The challenges court reform efforts face after authoritarian rule in Indonesia include the culture of corruption, a lack of professionalism and expertise, and legal uncertainty. Like other countries that have made a transition from authoritarian rule, Indonesia has engaged in an extensive period of court reform, and in many respects these efforts remain ongoing. I have identified that specialized courts have been a key part of its court reform strategy.

Lev offers a means of understanding the challenges of court reform after authoritarian rule. He is conscious of the interconnected nature of legal and political institutions. His work identifies how legal culture in Indonesia's courts under Suharto was marked by a decline in professionalism and a rise in corruption. 
In many respects, specialized courts are a deliberate effort to create judicial institutions that are independent from the general courts, and so by definition do not seek to tackle the problems of corruption within the general courts.

The judiciary in Indonesia has changed significantly over the past twenty years. Specialized courts have been set up in ways that differ from the general courts in the scope of their powers, the composition of the bench and the procedural requirements of the court. Specialized courts face common challenges, such as becoming established as a new judicial institution in the absence of support from the executive or legislature; balancing career judges with non-career judges and managing interpersonal rivalries; and becoming financially secure as a judicial institution. In addition to these challenges, there remain problems related to corruption, professionalism and competence in the courts that require long-term efforts at reform.

Court reform after authoritarian rule clearly faces significant challenges because the legacies of judicial culture are not easily overcome by institutional reform. Specialized courts do offer one strategy for reform, but it is no easy solution to issues entrenched from decades of authoritarian rule. What specialized courts have done is offer an opportunity to think creatively and reimagine judicial structures and court procedures. In particular, through the creation of non-career judges, the courts are led by experts, such as academics, who would not otherwise work in the courts. This institutional change has challenged legal culture in terms of what it means to be a judge and what is the role of the courts. Overall, Indonesia's experiment with specialized courts suggests that while these new institutions may go some way towards addressing issues of judicial independence, corruption and expertise, this must not come at the expense of addressing issues with the general courts as a whole.

\section{BIBLIOGRAPHY}

Amanda, Putri K. Shaila Tieken, Sharyn Graham Davies and Santi Kusumaningrum. “The Juvenile Courts and Children's Rights: Good Intentions, Flawed 
Execution." In The Politics of Court Reform: Judicial Change and Legal Culture in Indonesia, edited by Melissa Crouch. Cambridge: Cambridge University Press 2019.

Assegaf, Rifqi. "The Supreme Court: Reformasi, Independence and the Failure to Ensure Legal Certainty." In The Politics of Court Reform: Judicial Change and Legal Culture in Indonesia, edited by Melissa Crouch. Cambridge: Cambridge University Press 2019.

Bedner, Adriaan. Administrative Courts in Indonesia: A Socio-Legal Study. The Hague: Kluwer Law International, 2001.

Bedner, Adriaan. "Rebuilding the Judiciary in Indonesia: The Special Courts Strategy." Yuridika 23, no. 3 (2008).

Bedner, Adriaan and Herlambang Perdana Wiratraman. "The Administrative Courts: The Quest for Consistency." In The Politics of Court Reform: Judicial Change and Legal Culture in Indonesia, edited by Melissa Crouch. Cambridge: Cambridge University Press 2019.

Butt, Simon. Corruption and Law in Indonesia. London, New York: Routledge, 2012.

Butt, Simon. The Constitutional Court and Democracy in Indonesia. Leiden: Brill Nijhoff, 2015.

Butt, Simon, Rosalind Dixon, and Melissa Crouch. "Special Issue: The First Decade of Indonesia's Constitutional Court." Australian Journal of Asian Law 16, no. 2 (2016).

Butt, Simon. "Indonesia's Anti-corruption Courts and the Persistence of Judicial Culture." In The Politics of Court Reform: Judicial Change and Legal Culture in Indonesia, edited by Melissa Crouch. Cambridge: Cambridge University Press 2019 .

Cammack, Mark. “Indonesia's Human Rights Court." In New Courts in Asia, edited by Andrew Harding and Pip Nicholson. London: Routledge, 2010.

Cotterrell, Roger. Law, Culture and Society: Legal Ideas in the Mirror of Social Theory. Aldershot: Ashgate, 2006. 
Cotterrell, Roger. "The Sociological Concept of Law." Journal of Law and Society 10 (1983).

Crouch, Melissa. "Judicial Review and Religious Freedom: The Case of Indonesian Ahmadis." Sydney Law Review 34, no. 3 (2012).

Crouch, Melissa. "Asian Legal Transplants and Lessons on the Rule of Law: National Human Rights Commissions in Indonesia and Myanmar." Hague Journal of the Rule of Law, 15, no. 2 (2013).

Crouch, Melissa. Law and Religion in Indonesia: Conflict and the Courts in West Java. London: Routledge, 2014.

Crouch, Melissa. "Constitutionalism, Islam and the Practise of Religious Deference: The Case of the Indonesian Constitutional Court." Australian Journal of Asian Law 16, no. 2 (2016).

Crouch, Melissa. "Islamic Law and Society in Southeast Asia." In The Oxford Handbook of Islamic Law, edited by Anver M. Emon and Rumee Ahmed. Oxford: Oxford University Press, 2016.

Crouch, Melissa. "The Expansion of Emergency Powers: Social Conflict and the Military in Indonesia." Asian Studies Review 41, no. 3 (2017).

Crouch, Melissa. "Religion, Constitutionalism and Inequality: Perspectives from Asia." Asian Journal of Comparative Law 13, no. 2 (2018).

Crouch, Melissa and Antje Missbach. "The Criminalisation of People Smuggling: Legal Insights from Indonesia." Australian Journal of Asian Law 14, no. 2 (2013).

Engel, David M. "The Uses of Legal Culture in Contemporary Socio-Legal Studies:

A Response to Sally Engle Merry." Journal of Comparative Law 5 (2010).

Engel, David M. and Jaruwan S. Engel. Tort, Custom and Karma: Globalisation and Legal Consciousness in Thailand. Stanford: Stanford University Press, 2010. Feener, Michael. Sharia and Social Engineering: The Implementation of Islamic Law in Contemporary Aceh, Indonesia. Oxford: Oxford University Press, 2014. 
Friedman, Lawrence. "Legal Culture and Social Development." Law and Society Review 4 (1969).

Friedman, Lawrence. Law and Society: An Introduction. Englewood Cliffs: Prentice-Hall, 1977.

Geertz, Clifford. "Ideology as a Cultural System." In Ideology and Discontent, edited by David Apter. New York: Free Press of Glencoe, 1964.

Geertz, Clifford. “Thick Description: Toward an Interpretive Theory of Culture.” In The Interpretation of Cultures: Selected Essays. New York: Basic Books, 1973. Halliday, Simon and Bronwyn Morgan. "I Fought the Law and the Law Won? Legal Consciousness and the Critical Imagination." Current Legal Problems 66 (2013).

Huis, Stijn Cornelis van. “The Religious Courts: Does Lev's Analysis Still Hold?” In The Politics of Court Reform: Judicial Change and Legal Culture in Indonesia, edited by Melissa Crouch. Cambridge: Cambridge University Press 2019.

Indrayana, Denny. Indonesian Constitutional Reform 1999-2002: An Evaluation of Constitution-Making in Transition. Jakarta: Kompas, 2008.

Juwana, Hikmahanto. "Courts in Indonesia: A Mix of Western and Local Character." In Asian Courts in Context, edited by Jiunn-rong Yeh and Wen-Chen Chang. Cambridge: Cambridge University Press, 2014.

Kadafi, Binziad. “The Small Claims Court: An Innovation in Judicial Reform.” In The Politics of Court Reform: Judicial Change and Legal Culture in Indonesia, edited by Melissa Crouch. Cambridge: Cambridge University Press 2019.

Klare, Karl E. "Legal Culture and Transformative Constitutionalism." South African Journal on Human Rights 14 (1998).

Lev, Daniel S. “The Politics of Judicial Development in Indonesia." Comparative Studies in Society and History 7 (1965).

Lev, Daniel S. Islamic Courts in Indonesia: A Study in the Political Bases of Legal Institutions. Berkley: University of California Press, 1972. 
Lev, Daniel S. "Judicial Institutions and Legal Culture." In Culture and Politics in Indonesia, edited by Claire Holt Ithaca, NY: Cornell University Press, 1972.

Lev, Daniel S. "Judicial Unification in Post-Colonial Indonesia." Indonesia 16 (1973).

Lev, Daniel S. "Social Movements, Constitutionalism, and Human Rights." In Constitutionalism, Democracy, and the Transformation of the Modern World, edited by Douglas Greenberg, Stanley N. Katz, Melanie Oliviero and Steven Wheatley. London and New York, NY: Oxford University Press, 1993.

Lev, Daniel S. "Between State and Society: Professional Lawyers and Reform in Indonesia." In Making Indonesia, edited by Daniel S. Lev and Ruth McVey. Ithaca: Cornell Southeast Asia Program Publications, 1996.

Lev, Daniel S. "Comments on the Course of Legal Reform in Modern Indonesia." In Indonesia: Bankruptcy, Law Reform, and the Commercial Court, edited by Tim Lindsey. Sydney: Desert Pea Press, 2000.

Lev, Daniel S. "Introduction." In Legal Evolution and Political Authority in Indonesia: Selected Essays. The Hague: Kluwer Law International, 2000.

Lev, Daniel S. Legal Evolution and Political Authority in Indonesia: Selected Essays. The Hague: Kluwer Law International, 2000.

Lev, Daniel S. "Conceptual Filters and Obfuscation in the Study of Indonesian Politics." Asian Studies Review 29, no. 4 (2005).

Lev, Daniel S. "State and Law Reform in Indonesia." In Law Reform in Developing and Transitional States, edited by Tim Lindsey. London: Routledge, 2005.

Linnan, David. "Commercial Law Enforcement in Indonesia: The Manulife Case." In Indonesia: Law \& Society, edited by. Tim Lindsey. Sydney: Federation Press, 2008.

Linnan, David. "Reading the Tea Leaves in the Indonesian Commercial Court: A Cautionary Tale, But for Whom?" In New Courts in Asia, edited by Andrew Harding and Pip Nicholson. London: Routledge, 2010.

Merry, Sally Engle. "What is Legal Culture? An Anthropological Perspective." Journal of Comparative Law 5 (2010). 
Nelken, David. “Towards a Sociology of Legal Adaptation." In Adapting Legal Cultures, edited by David Nelken and Johannes Feest. Oxford: Hart Publishing, 2001.

Nelken, David. "Legal Cultures." In The Blackwell Companion to Law and Society, edited by Austin Sarat. Malden: Blackwell Publishing, 2003.

Nelken, David. "Comparative Legal Research and Legal Culture: Facts, Approaches, and Values." Annual Review of Law and Social Science 12 (2016).

Nicholson, Pip and Andrew Harding. New Courts in Asia. London: Routledge, 2010 .

Perry, Nick. "Daniel Lev; Scholar, Friend of Indonesia." Seattle Times, August 1, 2006, http://old.seattletimes.com/html/obituaries/2003166510_levobito1m. html.

Pompe, Sebastiaan. “In Memoriam, Daniel S. Lev (1933-2006)." Indonesia 93 (2012). Pompe, Sebastiaan. The Supreme Court of Indonesia: A Study of Institutional Collapse. Ithaca: Cornell University Press, 2005.

Reerink, Gustaaf, Kevin Omar Sidharta, Aria Suyudi and Sophie Hewitt. "The Commercial Courts: A Story of Unfinished Reforms." In The Politics of Court Reform: Judicial Change and Legal Culture in Indonesia, edited by Melissa Crouch. Cambridge, Cambridge University Press 2019.

Riles, Annelise. "A New Agenda for the Cultural Study of Law: Taking on the Technicalities." Buffalo Law Review 53 (2005).

Rosen, Lawrence. Law and Culture: An Invitation. Princeton: Princeton University Press, 2006.

Saptaningrum, Indriaswati Dyah. "The Fisheries Court: Government-Led Judicial Development." In The Politics of Court Reform: Judicial Change and Legal Culture in Indonesia, edited by Melissa Crouch. Cambridge, Cambridge University Press 2019. 
Setiawan, Ken. “The Human Rights Courts: Embedding Impunity." In The Politics of Court Reform: Judicial Change and Legal Culture in Indonesia, edited by Melissa Crouch. Cambridge, Cambridge University Press 2019.

Shapiro, Martin. Courts, a Comparative and Political Analysis. Chicago: University of Chicago Press, 1981.

Silbey, Susan S. "After Legal Consciousness." Annual Review of Law and Social Science 1 (2005).

Susan S. Silbey. "Making a Place for Cultural Analyses of Law. Law E Social Inquiry, Vol. 17, no 1 (Winter, 1992).

Tjandra, Surya. Labour Law and Development in Indonesia. Leiden: Leiden University Press, 2016.

Tjandra, Surya. "The Industrial Relations Court: Challenges for Labour Rights." In The Politics of Court Reform: Judicial Change and Legal Culture in Indonesia, edited by Melissa Crouch. Cambridge, Cambridge University Press 2019. 